\title{
Effect of feeding mixed microbial culture fortified with trace minerals on ruminal fermentation, nutrient digestibility, nitrogen and trace mineral balance in Sheep
}

\author{
W. S. Kwak , Y. I. Kim, D. Y. Choi and Y. H. Lee
}

\begin{abstract}
Background: The aim of the present study was to determine the effects of feeding trace mineralsfortified mixed microbial culture (TMC) on ruminal fermentation, nutrient digestibility, blood electrolyte status, nitrogen balance, and trace mineral balance in sheep.

Methods: Mixed microbes [0.6 \% (v/w) of Enterobacter sp., Bacillus sp., Lactobacillus sp., and Saccharomyces sp.] were cultured with $99 \%$ feedstuffs and $0.4 \%$ trace minerals including zinc and copper for ensiling. Six sheep (a mean body weight of $46.5 \pm 1.2 \mathrm{~kg}$ ) were fed two diets: a control diet (concentrate mix and rye straw) and an experimental diet (a control diet $+3.1 \%$ TMC).

Results: TMC feeding did not induce negative effects on ruminal fermentation, nutrient digestibility, blood electrolytes, and nitrogen balance in sheep. Feeding with TMC increased the intake of trace minerals $(p<0.05)$ and did not affect absorption of trace minerals in the whole digestive tract. Feeding with TMC increased fecal excretion and absorbable intake, and retention of zinc and copper $(p<0.05)$ by $71 \%$ and $77 \%$, respectively.

Conclusion: Feeding with TMC resulted in higher zinc and copper bioavailability and retention without any adverse effects on sheep performance.
\end{abstract}

Keywords: Microbial culture, Trace mineral, Absorption, Excretion, Retention, Sheep

\section{Background}

Feeding animals with microbials directly improves ruminal acidosis prevention, gut microbial balance, feed intake, weight gain, and feed efficiency in ruminants [1-3]. For instance, feeding with yeast culture increased feed intake in lactating cows $[4,5]$ and Hereford steers $[6,7]$, resulting in better animal performance. The use of microorganisms in animal diets has been shown to improve trace mineral balance. Yeast culture supplementation improved the retention of zinc and iron in lambs [7] and copper and iron in growing ruminants [1]. Feeding with mixed microbial (Bacillus and Saccharomyces) culture was shown to improve bioavailability of trace minerals (zinc, copper, and iron) to beef steers [8].

\footnotetext{
* Correspondence: wsk@kku.ac.kr

Division of Food Biosciences, College of Health and Medical Life Sciences,

Konkuk University, Chung-Ju, Chung-Buk 380-701, Korea
}

Trace mineral deficiency affects almost all physiological processes like growth, reproduction, immunity, milk production and other functions of animals [9]. Dietary trace minerals such as zinc and copper are essential components of enzymes needed for growth and lactation [10]. Fat metabolism seems to be associated with zinc. The glucose incorporation into fatty acids is greatly reduced in zinc-deficient animals [11]. According to previous studies, addition of zinc to cattle diets improves the growth of animals and carcass characteristics $[12,13]$.

Copper deficiency is an important problem in ruminants in many areas of the world. Copper deficiency frequently occurs because copper antagonists that reduce the bioavailability of copper, such as molybdenum, sulfur, and iron, are often high in ruminant diets [14]. Relatively low dietary concentrations of sulfur and molybdenum can increase copper requirement by 2 to 3 -fold [10]. Copper 
supplementation affected lipid metabolism by reducing cholesterol concentrations in the longissimus muscle of Brangus bulls in the study of Netto et al. [15]. Indoor confinement systems of cattle lowered zinc and copper intake from pastures and soils. Zinc and copper supplementation of cattle diets becomes increasingly important with regard to the greater use of high concentrate feeds [11]. In practice, feed manufacturers use higher concentration of zinc and copper than those specified for ruminants to achieve the maximum performance [16]. Zinc and copper supplementation in human food is especially important for pregnant women, and people consuming less animal products rich in zinc and copper [11]. As found in our previous research, feeding a combination of mixed microbial culture and clay minerals to beef steers increased the concentrations of zinc and copper in the longissimus muscle [8]. Feeding with trace minerals-fortified mixed microbial culture (TMC)-supplemented diet increased concentrations of certain trace minerals in the longissimus muscle of Hanwoo steers [17]. Thus, in the current research, we hypothesized that supplementing a mixed microbial culture with trace minerals (zinc and copper) will positively affect the ruminant performance and still increase bioavailability or retention of zinc and copper when the dietary zinc and copper contents increase from 1.5 -fold to 2.5 -fold of dietary requirement.

Accordingly, the aim of the study was to evaluate the effects of TMC on nutrient digestibility, ruminal fermentation, blood electrolytes, nitrogen $(\mathrm{N})$ balance, and trace mineral balance of sheep.

\section{Methods}

\section{Preparation of TMC}

The mixed microbial inoculants used in during experiments were isolated from the spent mushroom substrate and identified previously in our lab $[18,19]$. Mixed bacteria culture included highly cellulolytic bacteria such as Enterobacter ludwigii KU201-3, Bacillus cereus KU2063 , and Bacillus subtilis KU3, anaerobic fermentationstimulating lactic acid bacteria such as Lactobacillus plantarum KU5, and commercial Saccharomyces cerevisiae. Each of these strains was inoculated at $0.12 \%$ of the mixture. Bacillus sp. and Enterobacter sp. were cultured in plate containing count broth $(5 \mathrm{~g}$ casein, $2.5 \mathrm{~g}$ yeast extract, and $1 \mathrm{~g} / \mathrm{L}$ dextrose) at $36{ }^{\circ} \mathrm{C}$ for $24 \mathrm{~h}$. Lactobacillus sp. was cultured in MRS broth (0881, Difco Laboratories Inc., Detroit, MI, USA) at $36{ }^{\circ} \mathrm{C}$ for 24 h. Saccharomyces sp. was cultured in yeast malt broth (0711, Difco Laboratories Inc.) at $30^{\circ} \mathrm{C}$ for $48 \mathrm{~h}$.

These microbes $(0.6 \% \mathrm{v} / \mathrm{w})$ were inoculated into the mixture of $24.4 \%$ defatted rice bran, $19.6 \%$ ground corn grain, $16.0 \%$ soybean meal, $20.0 \%$ bentonite, $12.2 \%$ spent mushroom substrate, $3.3 \%$ jujube (low quality), $2.5 \%$ molasses, $1.6 \% \mathrm{MgO}$, and $0.4 \%$ trace minerals, fermented for $5 \mathrm{~d}$, and dried. In order to obtain the treated diet, trace minerals, such as zinc sulfate and copper sulfate, were added to microbial culture in the amount approximately 3-fold higher than the dietary requirement of sheep [10]. The chemical and trace mineral composition of TMC as well as the content of concentrate mix and rye straw fed to sheep are presented in Table 1. The crude protein (CP) and copper content of rye straw were similar to those $(3.0 \% \mathrm{CP}$ and $4.0 \mathrm{ppm}$ copper) presented in NRC [20]. Zinc concentrations in rye straw were much lower than those in typical cereal grain and pasture herbage (20-30 ppm) [10]. Drinking water from the underground source contained $0.33 \mathrm{ppm}$ iron, $0.02 \mathrm{ppm}$ manganese, $2.8 \mathrm{ppm}$ zinc, $0.65 \mathrm{ppm}$ copper, $0.03 \mathrm{ppm}$ cobalt, and $0.03 \mathrm{ppm}$ molybdenum (data not presented).

The ingredient, chemical, and trace mineral composition of the control and treated diets fed to sheep are presented in Table 2. The TMC-added diet contained zinc in the amount 1.6-fold higher and copper in the amount 1.9-fold higher than that in the control diet.

\section{Animals, feeding and experimental design}

All animal care protocols were approved by the Konkuk University Institutional Animal Care and Use Committee. Six 3-yr old sheep (a mean body weight of $46.5 \pm$ $1.2 \mathrm{~kg}$ ) were randomly allotted to two dietary treatments

Table 1 Chemical composition of feedstuffs fed to sheep ${ }^{a}$

\begin{tabular}{llll}
\hline Item & Concentrate mix & Rye straw & TMC $^{\text {b }}$ \\
\hline Dry matter, \% & 88.0 & 87.5 & 81.7 \\
Organic matter, \% & 91.8 & 92.8 & 68.6 \\
Ether extract, \% & 2.8 & 0.2 & 0.2 \\
Crude protein, \% & 17.4 & 3.1 & 16.1 \\
Neutral detergent fiber, \% & 31.5 & 72.5 & 23.4 \\
Acid detergent fiber, \% & 16.2 & 45.7 & 12.3 \\
Crude fiber, \% & 11.0 & 36.5 & 7.0 \\
Nitrogen free extracts, \% & 60.7 & 53.0 & 45.3 \\
Crude ash, \% & 8.2 & 7.2 & 31.4 \\
Ca, \% & 1.14 & 0.26 & 0.90 \\
P, \% & 0.58 & 0.10 & 0.23 \\
Trace mineral, ppm & & & \\
Zn & 83.5 & 9.8 & $1,149.5$ \\
Cu & 21.3 & 4.1 & 410.1 \\
Co & 0.02 & 0.01 & 3.59 \\
Fe & 884.3 & 65.9 & $4,230.5$ \\
Mn & 130.9 & 47.0 & 233.3 \\
Mo & 0.29 & 0.23 & $\mathrm{nd}$ \\
\hline
\end{tabular}

${ }^{\mathrm{a}}$ On a dry matter basis

${ }^{\mathrm{b}} \mathrm{TMC}=$ trace mineral-fortified microbial culture

${ }^{c}$ nd $=$ not detected 
Table 2 Ingredient, chemical, and trace mineral composition of control diet and diet added with trace mineral-fortified microbial culture $(T M C)^{a}$

\begin{tabular}{|c|c|c|}
\hline Items & Control & TMC added \\
\hline \multicolumn{3}{|l|}{ Ingredient composition (g/d) } \\
\hline Concentrate mix & 510.0 & 510.0 \\
\hline Rye straw & 340.0 & 340.0 \\
\hline Total & 850.0 & 876.1 \\
\hline \multicolumn{3}{|l|}{ Chemical composition (\%) } \\
\hline Dry matter & 87.8 & 87.6 \\
\hline Organic matter & 92.2 & 91.5 \\
\hline Crude protein & 11.7 & 11.8 \\
\hline Ether extract & 1.8 & 1.7 \\
\hline Crude fiber & 21.2 & 20.7 \\
\hline Neutral detergent fiber & 47.9 & 47.1 \\
\hline Acid detergent fiber & 28.0 & 27.5 \\
\hline Nitrogen free extracts & 57.6 & 57.2 \\
\hline Crude ash & 7.8 & 8.6 \\
\hline $\mathrm{Ca}$ & 0.79 & 0.79 \\
\hline$P$ & 0.39 & 0.39 \\
\hline \multicolumn{3}{|c|}{ Trace mineral composition, mg/kg } \\
\hline $\mathrm{Zn}$ & 54.0 & 89.0 \\
\hline $\mathrm{Cu}$ & 14.4 & 27.1 \\
\hline $\mathrm{Co}$ & 0.02 & 0.11 \\
\hline $\mathrm{Fe}$ & 557.0 & 674.3 \\
\hline $\mathrm{Mn}$ & 97.4 & 101.7 \\
\hline Mo & 0.26 & 0.25 \\
\hline
\end{tabular}

${ }^{\mathrm{a} O n}$ a dry matter basis

as shown in the Table 2: a control diet (formulated concentrate mix and rye straw) and a treated diet (control diet $+3.1 \%$ TMC). Dietary ingredients were mixed daily. Control diet dry matter (DM, approximately $1.8 \%$ of body weight) was fed in equal portions in the amount of $850 \mathrm{~g}$ at 07:00 and 18:00 $\mathrm{h}$. TMC was top-dressed on feed for the treated group. The amount of diet DM corresponded to the requirements of sheep [20]. During the experiment, sheep always had free access to fresh water. Diets were randomly assigned to sheep at the start of each trial provided that sheep would not receive the same diet in two consecutive trials. A switch-over design was used in this study. Each trial consisted of $5 \mathrm{~d}$ transition, $10 \mathrm{~d}$ preliminary, and $7 \mathrm{~d}$ collection periods. The number of observations per treatment was 6 .

During the experiment, the animals were kept in individual metabolism crate $(1.6 \mathrm{~m} \times 0.5 \mathrm{~m})$ that permitted separate collection of feces and urine. Daily fecal output during the collection period was dried at $60{ }^{\circ} \mathrm{C}$. Feces were thoroughly mixed at the end of the collection period to obtain a composite sample, which was ground through a $2 \mathrm{~mm}$ screen prior to storage. Daily urine output was collected in plastic bottles containing $15 \mathrm{ml}$ of $13.5 \mathrm{~N} \mathrm{H}_{2} \mathrm{SO}_{4}$. After weighing, $2 \%$ of the urine volume was refrigerated and bulked for the collection period.

About $250 \mathrm{ml}$ of ruminal fluid was obtained through the throat. Fluid was strained through four layers of gauges prior to the determination of $\mathrm{pH}$. Five $\mathrm{ml}$ of fluid were transferred to a tube containing two drops of concentrated $\mathrm{H}_{2} \mathrm{SO}_{4}$ and another $5 \mathrm{ml}$ to a tube containing $1 \mathrm{ml}$ of $25 \% \mathrm{wt} / \mathrm{vol}$ of metaphosphoric acid plus $5 \mathrm{ml}$ isocaproic acid for the determination of $\mathrm{NH}_{3}-\mathrm{N}$ and volatile fatty acids (VFA), respectively. Samples were stored at $-20^{\circ} \mathrm{C}$. In addition, on the last day of each trial, blood samples were taken via jugular venipuncture $6 \mathrm{~h}$ after feeding, added into bottles with anticoagulant ethylenediaminetetraacetic acid, and stored at $-20{ }^{\circ} \mathrm{C}$ for subsequent analysis.

\section{Chemical analysis}

Representative samples of the test feeds offered to the sheep were collected and stored at $-20{ }^{\circ} \mathrm{C}$ for further analysis. Immediately before the analysis, all the samples were dried and ground to pass through a 1-mm filter using a sample mill (Cemotec, Tecator, Sweden). The DM fraction was quantified by drying the samples at $60{ }^{\circ} \mathrm{C}$ for $48 \mathrm{~h}$ until constant weight. The crude protein $(\mathrm{CP})$, ether extract (EE), neutral detergent fiber (NDF), acid detergent fiber (ADF), crude fiber, and crude ash contents were determined following AOAC [21].

Ruminal $\mathrm{NH}_{3}-\mathrm{N}$ was determined according to Chaney and Marbach [22]. Ruminal VFA was determined according to Erwin et al. [23]. For mineral analysis, samples were analyzed for calcium, phosphorus, potassium, sodium, chlorine, zinc, copper, cobalt, iron, manganese, and molybdenum by inductively coupled argon plasma emission spectroscopy (ICP-OES 5300DV, Perkin Elmer, Billerica, Massachusetts, USA) as described by Braselton et al. [24].

\section{Statistical analysis}

Data were subjected to one-way analysis of variance (ANOVA) using the general linear model procedure for a completely random design [25]. The model included diet, trial, and interaction between diet and trial. Interaction effects for all dependent variables (parameters observed) were non-significant $(P>0.1)$, and were removed from the model. A comparison between the mean values of the control and treated diets was made using a student's $t$ test. [25] The differences were considered statistically significant at $p<0.05$. 
Table 3 Ruminal parameters of sheep fed fed trace mineral-fortified microbial culture (TMC)

\begin{tabular}{lllll}
\hline Item & Control & TMC added & SE & $p$ value \\
\hline Ruminal pH & 6.41 & 6.52 & 0.12 & 0.3861 \\
Ruminal total VFA ${ }^{1)}, \mu$ moles/ml & 47.1 & 47.2 & 8.9 & 0.9949 \\
Moles/100moles & & & & \\
$\quad$ Acetate & 72.2 & 73.1 & 1.2 & 0.4963 \\
$\quad$ Propionate & 17.8 & 16.7 & 2.0 & 0.6047 \\
Iso-butyrate & 0.22 & 0.22 & 0.02 & 0.8417 \\
Butyrate & 9.32 & 9.50 & 1.32 & 0.8891 \\
Iso-valerate & 0.19 & 0.22 & 0.05 & 0.5152 \\
$\quad$ Valerate & 0.25 & 0.27 & 0.04 & 0.6671 \\
Caproic acid & 0.02 & 0.03 & 0.01 & 0.6746 \\
Acetate/Propionate & 4.12 & 4.63 & 0.51 & 0.3421 \\
Ruminal NH${ }_{3}-\mathrm{N}$, mg/dl & 12.8 & 12.5 & 1.7 & 0.8629 \\
\hline Votide & & & &
\end{tabular}

1) Volatile fatty acids

$a, b$ Means with different superscripts within the same row are significantly different $(p<0.05)$

\section{Results}

Ruminal fermentation, nutrients digestibility, and $\mathrm{N}$ balance

Feeding TMC $(26.1 \mathrm{~g} / \mathrm{d})$ to sheep $(850 \mathrm{~g} / \mathrm{d}$ DM intake for the control group) did not affect ruminal fermentation such as ruminal $\mathrm{pH}$, VFA proportions and total VFA production, and $\mathrm{NH}_{3}-\mathrm{N}$ (Table 3). Feeding TMC to sheep did not affect the apparent digestibility of nutrients (Table 4). For $\mathrm{N}$ balance, feeding TMC increased $\mathrm{N}$ intake $(p<0.05)$, but did not affect fecal and urinary $\mathrm{N}$ excretion, and $\mathrm{N}$ retention (Table 5 ).
Table $\mathbf{5}$ Nitrogen balance of sheep fed trace mineral-fortified microbial culture $(T M C)^{1)}$

\begin{tabular}{lllll}
\hline Item & Control & TMC added & SE & $p$ value \\
\hline Intake, g/d & $15.9^{\mathrm{b}}$ & $16.5^{\mathrm{a}}$ & 0.1 & 0.0001 \\
Excretion, g/d & & & & \\
$\quad$ Fecal & 5.1 & 5.3 & 0.3 & 0.6181 \\
$\quad$ Urinary & 8.9 & 8.8 & 0.6 & 0.8203 \\
$\quad$ Total & 14.0 & 14.0 & 0.5 & 0.9656 \\
Absorption, g/d & 10.7 & 11.3 & 0.3 & 0.1203 \\
Retention & & & & \\
$\quad$ g/d & 1.8 & 2.5 & 0.5 & 0.1928 \\
$\quad \%$ intake & 11.6 & 15.0 & 2.8 & 0.2387 \\
\% absorbed & 17.1 & 22.2 & 4.1 & 0.2374 \\
\hline
\end{tabular}

1) On a dry matter basis

a,b Means with different superscripts within the same row are significantly different $(p<0.05)$

Trace mineral intake and apparent absorption Intake of almost all the trace minerals except for Mo increased $(p<0.05)$ in sheep fed with treated diet, because TMC was supplemented with zinc and copper and contained inherent cobalt, iron and manganese (Table 6). Apparent absorption of trace minerals was not affected by TMC feeding.

\section{Trace mineral excretion and retention}

Followed by the increased intake of trace minerals, TMC feeding increased fecal excretion of zinc, copper, cobalt, iron, and manganese $(p<0.05)$ (Table 7$)$. Urinary excretion of trace minerals was not different between the treatments. TMC feeding increased daily zinc and

Table 4 Apparent digestibility of nutrient by sheep fed trace mineral-fortified microbial culture (TMC) ${ }^{1)}$

\begin{tabular}{|c|c|c|c|c|}
\hline Item & Control & TMC added & SE & $p$ value \\
\hline & \multicolumn{4}{|c|}{-—-—-——-———— $\%$ - - - - - - - - } \\
\hline Dry matter & 67.8 & 67.8 & 0.7 & 0.9427 \\
\hline Organic matter & 70.1 & 70.5 & 0.8 & 0.5988 \\
\hline Ether extract & 86.0 & 86.1 & 1.9 & 0.9612 \\
\hline Crude protein & 67.7 & 68.1 & 1.8 & 0.8240 \\
\hline Neutral detergent fiber & 58.8 & 58.2 & 1.5 & 0.7157 \\
\hline Acid detergent fiber & 52.4 & 52.4 & 2.3 & 0.9924 \\
\hline Hemicellulose & 67.7 & 66.3 & 1.5 & 0.3879 \\
\hline Crude fiber & 51.3 & 51.5 & 2.0 & 0.9225 \\
\hline Nitrogen free extracts & 77.0 & 77.5 & 0.8 & 0.5250 \\
\hline Crude ash & 40.2 & 38.5 & 1.6 & 0.3194 \\
\hline Total digestible nutrient, \% & 66.5 & 66.4 & 0.7 & 0.8674 \\
\hline
\end{tabular}

\footnotetext{
${ }^{1)}$ On a dry matter basis
}

${ }^{\mathrm{a}, \mathrm{b}}$ Means with different superscripts within the same row are significantly different $(p<0.05)$ 
Table 6 Intake, absorbable intake and apparent absorbability of trace minerals by sheep fed trace mineral-fortified microbial culture $(\mathrm{TMC})^{1)}$

\begin{tabular}{|c|c|c|c|c|}
\hline Item & Control & TMC added & SE & $p$ value \\
\hline \multicolumn{5}{|c|}{ Intake, mg/d } \\
\hline $\mathrm{Zn}$ & $47.4^{\mathrm{b}}$ & $77.2^{\mathrm{a}}$ & 0.2 & $<0.0001$ \\
\hline $\mathrm{Cu}$ & $12.6^{\mathrm{b}}$ & $23.3^{\mathrm{a}}$ & 0.1 & $<0.0001$ \\
\hline Co & $0.02^{b}$ & $0.11^{\mathrm{a}}$ & 0.01 & $<0.0001$ \\
\hline $\mathrm{Fe}$ & $473.6^{b}$ & $584.0^{\mathrm{a}}$ & 0.1 & $<0.0001$ \\
\hline $\mathrm{Mn}$ & $82.8^{\mathrm{b}}$ & $88.9^{\mathrm{a}}$ & 0.1 & $<0.0001$ \\
\hline Mo & 0.24 & 0.24 & 0.01 & 0.3974 \\
\hline \multicolumn{5}{|c|}{ Absorbable intake, mg/d } \\
\hline $\mathrm{Zn}$ & $8.7^{b}$ & $14.9^{\mathrm{a}}$ & 2.0 & 0.0363 \\
\hline $\mathrm{Cu}$ & $2.33^{b}$ & $3.96^{\mathrm{a}}$ & 0.24 & 0.0088 \\
\hline Co & 0.001 & 0.002 & 0.03 & 0.5500 \\
\hline $\mathrm{Fe}$ & 120.8 & 137.8 & 24.7 & 0.5264 \\
\hline $\mathrm{Mn}$ & -1.24 & -0.44 & 1.37 & 0.5867 \\
\hline Mo & 0.057 & 0.053 & 0.030 & 0.9237 \\
\hline \multicolumn{5}{|c|}{ Apparent absorbability, \% } \\
\hline $\mathrm{Zn}$ & 18.4 & 19.3 & 3.4 & 0.8077 \\
\hline $\mathrm{Cu}$ & 18.5 & 17.0 & 1.5 & 0.3956 \\
\hline Co & 1.7 & 2.1 & 5.6 & 0.5544 \\
\hline $\mathrm{Fe}$ & 25.5 & 23.6 & 5.1 & 0.7312 \\
\hline $\mathrm{Mn}$ & -1.5 & -0.5 & 1.6 & 0.5597 \\
\hline Mo & 23.3 & 22.4 & 12.3 & 0.9433 \\
\hline
\end{tabular}

${ }^{1)}$ On a dry matter basis

${ }^{a, b}$ Means with different superscripts within the same row are significantly different $(p<0.05)$

copper retention $(p<0.05)$, and did not affect other trace mineral retention (Table 7).

In addition, TMC feeding did not affect blood electrolytes such as calcium, phosphorus, potassium, sodium, and chlorine (data not presented). It indicates that TMC feeding maintained normal metabolism and homeostasis of major minerals in the body.

\section{Discussion}

Rumen fermentation, nutrients digestibility, and $\mathrm{N}$ balance Feeding TMC to sheep did not affect ruminal fermentation, apparent digestibility of nutrients, and nitrogen balance in sheep. In spite of the high ash content (31.4\%) in TMC, the diet treated with TMC appeared to contain similar total digestible nutrients as the control diet. This finding suggests that feeding TMC positively affects nutrient digestion of the control (basal) diet. In previous studies, feeding direct-fed microbials (Enterococcus sp. and yeast sp.) to feedlot cattle affected ruminal fermentation and nutrient digestion through the decrease of ruminal $\mathrm{pH}$ and butyrate, and an increase of propionate [26]. Feeding Saccharomyces sp. and/or Clostridium sp.
Table 7 Trace mineral excretion and retention of sheep fed trace mineral-fortified microbial culture (TMC) ${ }^{1)}$

\begin{tabular}{cllll}
\hline Item & Control & TMC added & SE & $p$ value \\
\hline \multicolumn{5}{c}{ Fecal excretion } \\
Zn & $38.7^{\mathrm{b}}$ & $62.3^{\mathrm{a}}$ & 2.1 & 0.0004 \\
$\mathrm{Cu}$ & $10.3^{\mathrm{b}}$ & $19.3^{\mathrm{a}}$ & 0.3 & 0.0001 \\
$\mathrm{Co}$ & $0.0^{\mathrm{b}}$ & $0.1^{\mathrm{a}}$ & 0.1 & 0.0412 \\
$\mathrm{Fe}$ & $352.7^{\mathrm{b}}$ & $446.0^{\mathrm{a}}$ & 24.7 & 0.0195 \\
Mn & $84.0^{\mathrm{b}}$ & $89.3^{\mathrm{a}}$ & 1.4 & 0.0180 \\
Mo & 0.2 & 0.2 & 0.1 & 0.9818
\end{tabular}

Urinary excretion

$\mathrm{Zn} \quad \mathrm{nd}^{2)} \quad \mathrm{nd}$

$\mathrm{Cu} \quad 0.09$

Co nd

$\mathrm{Fe} \quad \mathrm{nd}$

$\mathrm{Mn} \quad \mathrm{nd}$

Mo $\quad 0.09$

$0.09-0.05$

0.05

0.10

0.6792

Retention

Zn $\quad 8.7^{\mathrm{b}}-14.9^{\mathrm{a}}-20$

$\mathrm{Cu} \quad 2.2$

Co $\quad 0.011$

$3.9^{a}$

0.0363

$0.011 \quad 0.015$

0.0048

$\begin{array}{lll}\mathrm{Fe} & 120.8 & 138.0\end{array}$

0.9900

Mn -1.2

Mo

$-0.036$

$-0.4$

0.5264

0.5867

1) On a dry matter basis. ${ }^{2)}$ nd $=$ not detected

a,b Means with different superscripts within the same row are significantly different $(p<0.05)$

increased the total ruminal VFA concentration, acetic acid proportion, and nutrient digestibility, and decreased propionate proportion in sheep [27]. Feeding ruminal cellulolytic bacteria culture to Hanwoo heifers increased concentration of ruminal butyrate and $\mathrm{NH}_{3}-\mathrm{N}$ but did not affect ruminal $\mathrm{pH}$ and concentrations of ruminal total VFA, acetate, propionate and valerate [28]. Such inconsistent results suggest that ruminal fermentation and nutrient digestibility vary depending on the species and the amount of microbes added to the diet.

Supplementing $20 \mathrm{mg} / \mathrm{kg}$ of zinc sulfate to the diet did not affect ruminal total VFA concentration and proportions [29]. According to Fathul and Wajizah [30], the addition of copper and manganese does not alter in vitro ruminal $\mathrm{pH}, \mathrm{NH}_{3}-\mathrm{N}$, and VFA. Similarly, mineral compounds did not affect ruminal $\mathrm{pH}$, VFA, and $\mathrm{NH}_{3}-\mathrm{N}$ in the study of Galyean and Chabot [31]. These results consistent between studies suggest that trace minerals have little effect on ruminal fermentation. 
According to the study of Cole et al. [7], lambs fed yeast culture had greater $\mathrm{N}$ balance than control lambs. This phenomenon was not observed in the present study.

\section{Intake and apparent absorption of trace minerals}

The intake of zinc and copper by sheep fed with treated diet increased by 63 and $89 \%$, respectively $(p<0.05)$. An apparent absorption of trace minerals was similar between sheep fed with TMC and control diets. This means that the supplementation of trace minerals did not decrease the apparent absorption of these minerals in sheep diet. As a result, absorbable intake of zinc and copper increased by 71 and $70 \%$, respectively. The apparent absorption of zinc $(18-19 \%)$ belonged to the generally common range, 15-60 \% as reported by McDowell [11]. High intake of divalent cations, such as copper, iron, and calcium, and phytate reduce zinc absorption [10]. The most important factor affecting zinc absorption is the zinc content of the diet [11]. In the present study, zinc supplementation at the marginal, not deficient dietary level, did not alter zinc absorption percentage.

Copper absorption $(17-18 \%)$ in the present study was higher than that $(<1.0$ to 10 percent) in ruminants [14]. Copper has complex interactions with sulfur and molybdenum in the ruminal environment. High dietary zinc and iron can reduce copper absorption in cattle and sheep [14, 32, 33]. In the present study, copper supplementation at the marginal, not deficient dietary level, did not alter copper absorption percentage, thus resulting in increased absorbable intake of copper.

Absorption of cobalt as found in the current study was $1.7-2.1 \%$ and fell in the range $1-2 \%$ as reported by Van Bruwaene et al. [34]. Absorption of iron and molybdenum was positive as reported by Ben-Ghedalia et al. [35]. However, apparent absorption of manganese was negative as reported by Solomon et al. [36] in sheep.

\section{Trace mineral excretion}

Fecal excretion of zinc and copper in sheep was higher by 61 and $87 \%$ respectively at TMC diet than control diet. The primary route of trace mineral excretion was through the feces rather than urine. Similar result was also observed for zinc. The primary route of zinc excretion was through the feces [37]. As observed in the present study, the urinary excretion of zinc by sheep was generally less than $1 \mathrm{mg} / \mathrm{d}$ with little effect on excretion due to zinc supply in the diet [10]. Copper also showed similar excretion pattern to zinc. As reported in previous studies, biliary excretion is the major mechanism responsible for copper homeostasis, which is less effective in sheep than cattle [38].

Absorbed cobalt is primarily excreted though the urine [39]. Cobalt concentrations were extremely low and not detectable in the present study. The primary routes of iron excretion are via feces and urine [11]. However, in the present study the fecal route appeared to be more important. Excretion of absorbed manganese in the bile occurs very rapidly [40]. In the present study, more endogenous manganese seemed to excrete via the feces than supplied manganese. Molybdenum was excreted through both the feces and urine. The results of present study are in agreement with the report of NRC [10] showing that feces serve major excretion pathway in ruminants, and body balance of molybdenum is controlled primarily by urinary excretion.

\section{Trace mineral retention}

Zinc retention and copper retention in sheep were higher by 71 and $77 \%$, respectively at TMC diet than that at the control diet. This phenomenon was observed consistently in previous studies, too. Supplementing yeast culture increased retention of zinc or copper in lambs [7, 41]. Feeding a combination of mixed microbial culture and clay minerals to beef steers increased concentrations of zinc and copper in the longissimus muscle [8]. Cao et al. [42] reported that zinc supplementation of ruminant diets deficient in zinc resulted in the increased zinc retention in the ruminant muscle. Supplementing zinc and other trace minerals increased concentrations of these minerals in the longissimus muscle of Hanwoo steers [7]. When the dietary zinc concentration was lower than $100 \mathrm{ppm}$ diet, the tissues of lambs did not accumulate zinc, but muscle zinc was higher at $100 \mathrm{ppm}$ zinc level than at $50 \mathrm{ppm}$ zinc level [43]. Retained zinc primarily accumulates in skeletal muscles and bones, as also suggested by Outten and O'Halloran [44]. The copper is mainly stored in liver. Increasing dietary copper at the deficient or marginal level does not increase the copper concentration in muscles [10]. In this study, higher amount of retained copper was expected to be stored primarily in liver.

Increased intake of cobalt did not result in higher cobalt retention, apparently due to higher fecal excretion. This observation may explain why supplemented cobalt did not accumulate in the longissimus muscle of Hanwoo steers in the study of Kwak et al. [17]. Henry et al. [45] reported that liver and kidney cobalt concentrations increase when animals are fed high dietary cobalt. However, this phenomenon was not observed in the current study.

The overall results of the present study indicate that a desirable trace mineral retention in sheep may happen when a diet is supplemented with both microbial culture and trace minerals. This phenomenon can be explained by an improved mineral uptake through the microbial bioconversion of inorganic trace minerals into more available organic minerals that may occur during the ensiling process and the ruminal fermentation process. To summarize, TMC feeding resulted in higher intake of 
trace minerals (especially $\mathrm{Zn}$ and $\mathrm{Cu}$ ), similar absorption, higher absorbable intake, higher fecal and similar urinary excretion, and higher retention.

\section{Conclusions}

The results of the current study suggest that supplementing a combination of mixed microbial culture and trace minerals improves the bioavailability and retention of zinc and copper in sheep without adverse effects on ruminal fermentation, nutrient digestibility, blood electrolytes, and nitrogen balance. The results of the present research can be used as a basis for producing healthier animal feed and animal products rich with certain trace minerals.

\section{Competing interests}

The authors declare that they have no competing interests.

\section{Authors' contributions}

$\mathrm{YH}$ made chemical analysis of the study. YI assisted the manuscript writing and standard form of the journal, and DY performed the statistical analysis. WS made substantial contributions to the study conception and design, and wrote the manuscript as the first and corresponding author. All authors read and approved the final manuscript.

\section{Acknowledgements}

This study was carried out with the support of the "Cooperative Research Program for Agriculture Science and Technology Development (Project No. PJ009382012015)", the Rural Development Administration, Republic of Korea.

Received: 25 June 2015 Accepted: 20 April 2016

Published online: 25 May 2016

\section{References}

1. Yoon IK, Stern MD. Influence of direct-fed microbes on ruminal microbial fermentation and performance of ruminants: a review. Asian-Aust J Anim Sci. 1995:8:533-55.

2. Krehbiel CR, Rust SR, Zhang G, Gilliland SE. Bacterial direct-fed microbials in ruminant diets: Performance response and mode of action. J Anim Sci. 2003;81:E120-32.

3. Zhou Q, Li K, Jun X, Bo L. Role and functions of beneficial microorganisms in sustainable aquaculture. Bioresour Technol. 2009;100:3780-6.

4. Williams PEV, Tait CAG, Innes GM, Newbold CJ. Effects of the inclusion of yeast culture (Saccharomyces cerevisiae plus growth medium) in the diet of dairy cows on milk yield and forage degradation and fermentation patterns in the rumen of steers. J Anim Sci. 1991;69:3016-26.

5. Robinson PH, Garrett JE. Effect of yeast culture (Saccharomyces cerevisiae) on adaptation of cows to postpartum diets and on lactational performance. J Anim Sci. 1999;77:988-99.

6. Adams DC, Galyean ML, Kiesling HE, Wallace JD, Finkner MD. Influence of viable yeast culture, sodium bicarbonate and monensin on liquid dilution rate, rumen fermentation and feedlot performance of growing steers and digestibility in lambs. J Anim Sci. 1981;53:780-9.

7. Cole NA, Purdy CW, Hutcheson DP. Influence of yeast culture on feeder calves and lambs. J Anim Sci. 1992;70:1682-90.

8. Kwak WS, Lee SM, Kim YI. Effects of dietary addition of bentonite and probiotics on meat characteristics and health of Hanwoo (Bos taurus coreanae) steers fed rice straw as a sole roughage source (a field study). J Kor Grassl Forage Sci. 2012;32:1-10.

9. Kundu MS, De AK, Jeyakumar S, Sunder J, Kundu A, Sujatha T. Effect of zinc supplementation on reproductive performance of Teressa goat. Vet World. 2014;7:380-3.

10. National Research Council. Mineral tolerance of animals. 2nd ed. Washing DC: The National Academy Press; 2005.

11. McDowell LR. Minerals in animal and human nutrition. Amsterdam: Elsevier; 2003.

12. Greene LW, Lunt DK, Byers FM, Chirase NK, Richmond CE, Knutson RE, et al. Performance and carcass quality of steers supplemented with zinc oxide or zinc methionine. J Anim Sci. 1988;66:1818-23.
13. Spears JW, Kegley EB. Effect of zinc source (zinc oxide vs. zinc proteinate) and level on performance, carcass characteristics, and immune response of growing and finishing steers. J Anim Sci. 2002;80:2747-52.

14. Underwood EJ, Suttle NF. The mineral nutrition of livestock. 3rd ed. New York: CABI Publishing; 1999.

15. Netto AS, Zanetti MA, Claro GRD, de Melo MP, Vilela FG, Correa LB. Effects of copper and selenium supplementation on performance and lipid metabolism in confined Brangus Bulls. Asian-Aust J Anim Sci. 2014;27:488-94.

16. National Research Council. Nutrient requirement of small ruminants. 7th ed. Washington, DC: The National Academy Press; 2007.

17. Kwak WS, Kim YI, Lee SM, Lee YH, Choi DY. Effect of feeding mixed microbial culture fortified with trace minerals on the performance and carcass characteristics of late fattening Hanwoo steers (a field study). Asian-Aust J Anim Sci. 2015;28:1592-98

18. Kim YI, Jung SH, Seok JS, Yang SY, Huh JW, Kwak WS. Isolation and identification of high cellulolytic bacteria from spent mushroom substrate and determination of optimal medium conditions for the growth. Korean J Microbiol Biotechnol. 2007;35:255-60.

19. Kim YI, Jeong SH, Seok JS, Yang SY, Huh JW, Kwak WS. Isolation and identification of hydrolytic enzyme-producing bacteria from spent mushroom substrate. J Anim Sci Technol. 2008;50:713-20.

20. National Research Council. Nutrient requirements of sheep. 6th ed. Washington, DC: The National Academy Press; 1985.

21. AOAC (Association of Official Analytical Chemists). Official methods of analysis. 17th ed. Washington, D. C: Association of Analytical Chemists; 2000.

22. Chaney AL, Marbach EP. Modified reagents for the determination of urea and ammonia. Clin Chem. 1962;8:130-2.

23. Erwin ES, Marco GJ, Emery EM. Volatile fatty acid analyses of blood and rumen fluid by gas chromatography. J Dairy Sci. 1961;44:1768-71.

24. Braselton WE, Stuart KJ, Mullaney TP, Herdt TH. Biopsy mineral analysis by inductively coupled plasma-atomic emission spectroscopy with ultrasonic nebulization. J Vet Diagn Investig. 1997:9:395-400.

25. Statistix7. User's manual. Tallagassee: Analytical Software; 2000.

26. Beauchemin KA, Yang WZ, Morgavi DP, Ghorbani GR, Kautz W, Leedle JAZ. Effects of bacterial direct-fed microbials and yeast on site and extent of digestion, blood chemistry, and subclinical ruminal acidosis in feedlot cattle. J Anim Sci. 2003;81:1628-40.

27. Jin GL, Choi SK, Choi SH, Song MK. Effect of microbial additives on metabolic characteristics in sheep and milking performance of lactating dairy cows. J Anim Sci Technol. 2007:49:819-28.

28. Park JK, Jeong CS, Park DY, Kim HC, Lee SC, Kim CH. Effects of increasing inclusion levels of rumen cellulolytic bacteria culture on in vivo ruminal fermentation patterns in Hanwoo heifers. J Anim Sci Technol. 2009;51: $45-52$.

29. Spears JW, Schlegel P, Seal MC, Lloyd KE. Bioavailability of zinc from zinc sulfate and different organic zinc sources and their effects on ruminal volatile fatty acid proportions. Livestock Prod Sci. 2004;90:211-7.

30. Fathul F, Wajizah S. Additional micromineral $\mathrm{Mn}$ and $\mathrm{Cu}$ in relation to rumen biofermentation activities of sheep in vitro method. JITV. 2010;15:9-15.

31. Galyean ML, Chabot RC. Effects of sodium bentonite, buffer salts, cement kiln dust and clinoptilolite on rumen characteristics of beef steers fed a high roughage diet. J Anim Sci. 1981;52:1197-204.

32. WHO (World Health Organization). Copper, environmental health criteria 200. Geneva: World Health Organization; 1998.

33. Spears JW. Trace mineral bioavailability in ruminants. J Nutr. 2003:133:1506S-9S

34. Van Bruwaene R, Gerber GB, Kirchmann R, Colard J, Van Kerkom J. Metabolism of ${ }^{51} \mathrm{Cr},{ }^{54} \mathrm{Mn},{ }^{59} \mathrm{Fe}$ and ${ }^{60} \mathrm{Co}$ in lactating dairy cows. Health Phys. 1984;46:1069-82

35. Ben-Ghedalia D, Miron J, Yosef E. Apparent digestibility of minerals by lactating cows from a total mixed ration supplemented with poultry litter. J Dairy Sci. 1996;79:454-8.

36. Solomon R, Yosef E, Miron J, Dror Y, Ben-Ghedalia D. Absorption of macroand micro-elements by sheep from barley and barley plus sulphur dioxidetreated straw rations. Small Ruminant Res. 1991:6:55.

37. Miller WJ. Zinc nutrition of cattle: a review. J Dairy Sci. 1970;53:1123-35.

38. Saylor WW, Leach RM. Intracellular distribution of copper and zinc in sheep: effect of age and dietary levels of the metals. J Nutr. 1980;110: 448-59.

39. Kirchgessner M, Reuber S, Kreuzer M. Endogenous excretion and true absorption of cobalt as affected by the oral supply of cobalt. Biol Trace Elem Res. 1994;41:175-89. 
40. Malecki EA, Radzanowski GM, Radzanowski TJ, Gallaher DD, Greger JL. Biliary manganese excretion in conscious rats is affected by acute and chronic manganese intake but not by dietary fat. J Nutr. 1996;126:489-98.

41. Petersen MK, Streeter CM, Clark CK. Mineral availability with lambs fed yeast culture. Nutr Rep Int. 1987;36:521-5.

42. Cao J, Henry PR, Guo R, Holwerda RA, Toth JP, Littell RC, Miles RD, Ammerman CB. Chemical characteristics and relative bioavailability of supplemented organic zinc sources for poultry and ruminants. J Anim Sci. 2000;78:2039-54.

43. Sobhanirad S. Changes in blood and tissues zinc concentration in response to organic and inorganic sources in growing Baluchi lambs. Res Opin Anim Vet Sci. 2015;5:30-3.

44. Outten $\mathrm{CE}, \mathrm{O}^{\prime}$ Halloran TV. Femtomolar sensitivity of metalloregulatory proteins controlling zinc homeostasis. Science. 2001;292(5526):2488-92.

45. Henry PR, Littell RC, Ammerman CB. Effect of high dietary zinc concentration and length of zinc feeding on feed intake and tissue zinc concentration of sheep. Anim Feed Sci Technol. 1997;66:237-45.

Submit your next manuscript to BioMed Central and we will help you at every step:

- We accept pre-submission inquiries

- Our selector tool helps you to find the most relevant journal

- We provide round the clock customer support

- Convenient online submission

- Thorough peer review

- Inclusion in PubMed and all major indexing services

- Maximum visibility for your research

Submit your manuscript at www.biomedcentral.com/submit
Biomed Central 